\title{
Correction to: Inhibition of the key metabolic pathways, glycolysis and lipogenesis, of oral cancer by bitter melon extract
}

Subhayan Sur ${ }^{1 \dagger}$, Hiroshi Nakanishi ${ }^{1 \dagger}$, Colin Flaveny ${ }^{2}$, Joseph E. Ippolito ${ }^{3}$, Jane McHowat ${ }^{1}$, David A. Ford ${ }^{4}$ and Ratna B. Ray ${ }^{1 *}$

\section{Correction to: Cell Commun Signal \\ https://doi.org/10.1186/s12964-019-0447-y}

Following publication of the original article [1], it was reported that Fig. 1c was not entirely readable due to overlapping Fig. 1d. The publishers apologise for this error.

The updated Fig. 1 is supplied below. The original article [1] has been corrected.

\section{Author details}

${ }^{1}$ Department of Pathology, Saint Louis University, 1100 South Grand Boulevard, St. Louis, MO 63104, USA. ${ }^{2}$ Department of Pharmacology and Physiology, Saint Louis University School of Medicine, St. Louis, MO, USA. ${ }^{3}$ Mallinckrodt Institute of Radiology, Washington University in Saint Louis, School of Medicine, Saint Louis, MO, USA. ${ }^{4}$ Biochemistry and Molecular, Biology, Saint Louis University, Saint Louis, MO, USA.

Published online: 19 November 2019

\section{Reference}

1. Sur, et al. Inhibition of the key metabolic pathways, glycolysis and

lipogenesis, of oral cancer by bitter melon extract. Cell Commun Signal. 2019;17:131 https://doi.org/10.1186/s12964-019-0447-y.

* Correspondence: ratna.ray@health.slu.edu

†Subhayan Sur and Hiroshi Nakanishi contributed equally to this work.

'Department of Pathology, Saint Louis University, 1100 South Grand

Boulevard, St. Louis, MO 63104, USA

Full list of author information is available at the end of the article

(c) The Author(s). 2019 Open Access This article is distributed under the terms of the Creative Commons Attribution 4.0 International License (http://creativecommons.org/licenses/by/4.0/), which permits unrestricted use, distribution, and reproduction in any medium, provided you give appropriate credit to the original author(s) and the source, provide a link to the Creative Commons license, and indicate if changes were made. The Creative Commons Public Domain Dedication waiver (http://creativecommons.org/publicdomain/zero/1.0/) applies to the data made available in this article, unless otherwise stated. 
A
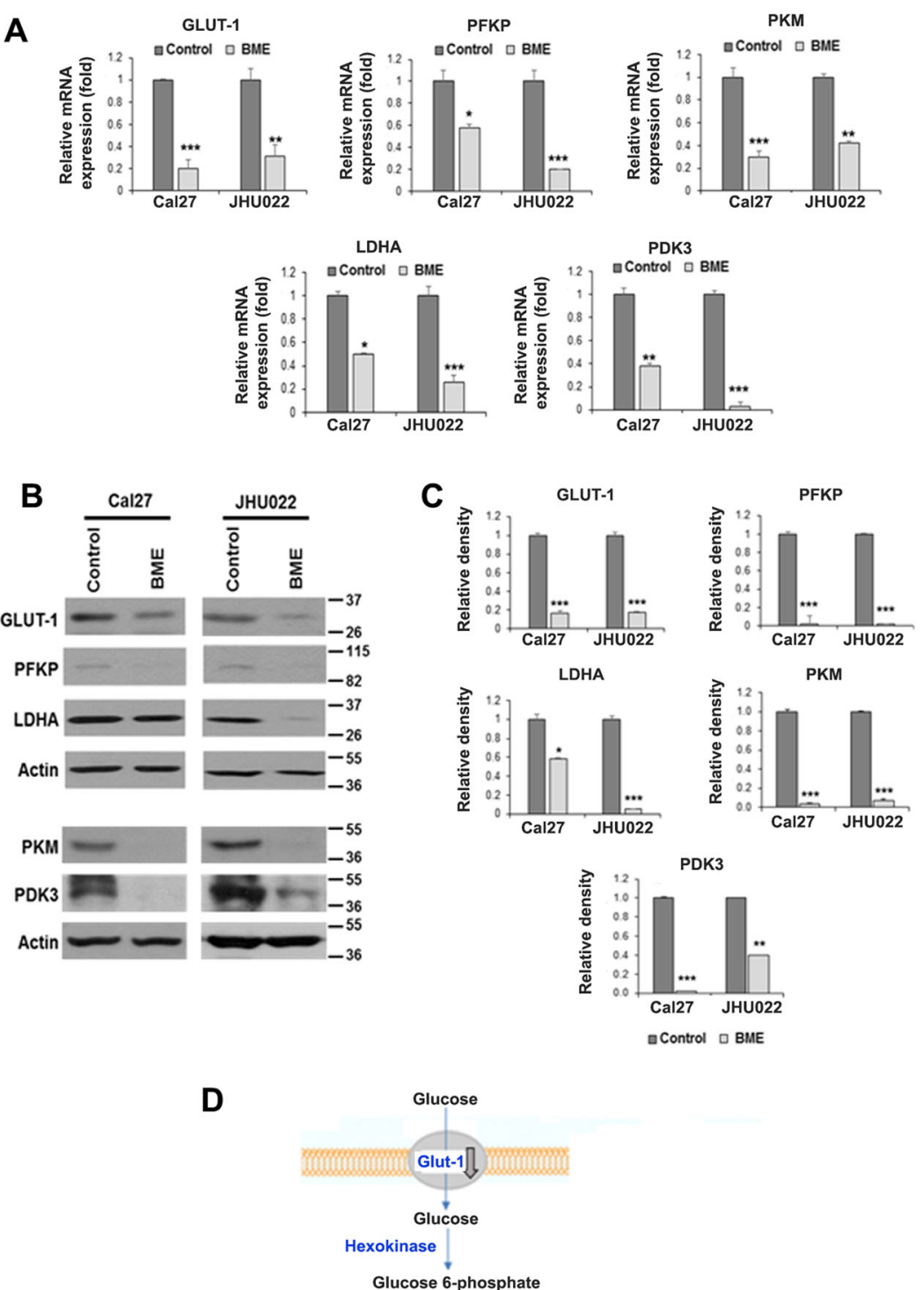

Phosphogluco isomerase

Fructose 6-phosphate

\Phosphofructo kinase

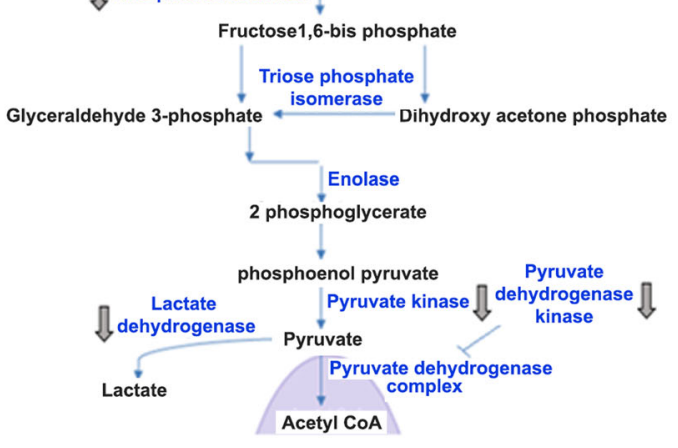

DDownregulated by BME

Fig. 1 (See legend on next page.) 
(See figure on previous page.)

Fig. 1 BME treatment reduces expression of glycolytic genes. a: Relative mRNA expression of GLUT-1, PFKP, PKM, LDHA, and PDK3 was analysed by q-RT-PCR in Cal27 and JHU022 cells with/without BME. $18 \mathrm{~s}$ gene was used as internal control. b: Cell lysates from Cal27 and JHU022 with or without BME treatment for $30 \mathrm{~h}$ were subjected to Western blot analysis for GLUT-1, PFKP, LDHA, PKM and PDK3 using specific antibodies. The membrane was reprobed with antibody to actin as an internal control. c: Quantitative of Western blot band intensities using Image-J software. Small bar indicates standard error $\left({ }^{*}, p<0.05 ;{ }^{* *}, p<0.01 ;{ }^{* * *} p<0.001\right)$. d: Schematic diagram showing different genes regulate glycolysis and effect of BME on the genes 